\section{Distribution of Shelters and Agriculture to Communities in the Siosar Refugee Relocation}

\author{
Agung Suharyanto ${ }^{1}$, Wiflihani ${ }^{2}$, Jamilah Nasution ${ }^{3}$ \\ ${ }^{1}$ Faculty of Political and Social Sciences, Universitas Medan Area, Indonesia \\ ${ }^{2}$ Faculty of Languages and Arts, Universitas Negeri Medan, Indonesia \\ ${ }^{3}$ Faculty of Sciences and Technology, Universitas Medan Area, Indonesia \\ Email: jamillah@staff.uma.ac.id
}

\section{Abstract:}

The Siosar area is an official shelter created by the government for communities directly affected by Mount Sinabung. The purpose of this research is to describe the distribution of shelter and agriculture to the community in the Siosar Refugee Relocation. Which methodThe method used is descriptive qualitative research method, which aims to present a picture of the social reality that exists in society by describing phenomena in the area. HThe results of the study can be drawn from the conclusions, namely: the community is very accepting of the distribution of land and settlements in the shelter, because the original location can no longer be lived in. The impact of daily income is also felt and hopes to get agricultural land to maintain income for daily life.

Keywords:

meaning; relocation; social reality

\section{Introduction}

Sinabung Volcano is a stratovolcano, administratively located in Karo Regency, North Sumatra Province, and geographically located at 3o 10' North Latitude, 980 23.5' East Longitude with an altitude of 2460 meters above sea level. In North Sumatra there are volcanoes that are still active and inactive, namely as follows, Mount Sibuatan which is the highest mountain in North Sumatra is not active. Gunung Sinabung which is one of the mountains that is still active in North Sumatra. Mount Sibayak is one of the active volcanoes in North Sumatra which is located in Karo Regency, precisely not far from the city of Berastagi. Disaster mitigation is a disaster management effort at the predisaster stage. Efforts aimed at reducing the impact of disasters both natural disasters, human disasters and a combination of both in a community which is then given responsibility to the government in collaboration with the local community or organizations in a particular area to carry it out. (Simamora, R. et al. 2021)

This mountain is not dangerous but still have to be careful. Because there is no recorded history of its activities since 1600, Gunung Sinabung is classified as a type B volcano. Since the eruption in 2010 until Tuesday, June 2, 2015 at 23.00 WIB, Gunung Sinabung continues to show volcanic activity. Gunung Sinabung which is increasingly increasing its volcanic activity has resulted in residents around Gunung Sinabung inevitably having to evacuate to shelters. It has been recorded that it has been more than 5 years since Gunung Sinabung erupted, causing physical damage and socio-economic conditions of the people who live and work around Gunung Sinabung. 


\section{Lakhomi Journal: Scientific Journal of Culture \\ ISSN: 2774-311X (Online), 2774-4728 (Print)}

Vol. 2, No. 3, September 2021, Page: 89-94

Email: lakhomijournal@gmail.com

The impact of the eruption of Gunung Sinabung was felt for the people who live around the foot of Gunung Sinabung, especially in areas whose radius is approximately $7 \mathrm{~km}$ from the summit of Gunung Sinabung. There are negative impacts that can be directly felt by residents, for example when Gunung Sinabung erupts, releasing hot clouds or large amounts of energy. The negative impact that cannot be felt directly by residents is when it comes to the physical condition of the people of Karo Regency. Due to the eruption of Gunung Sinabung, many residents were forced to evacuate to locations that were considered safer for their lives. The government's role in tackling this is really needed so that residents still feel safe and worthy even though they are evacuating (Ramadhan, and Matondang, 2016; Rambe, et al.,2016;Nugraha, \& Sulastri, 2018). The physical condition of the community can be in the form of social impacts, economic impacts, facilities and infrastructure impacts and defense impacts (Muary, et al., 2020). In this case, the social impact and the economic impact have a significant influence on the survival of the community, especially the farmers whose entire survival is at stake for agricultural land as their main livelihood.

During the Sinabung disaster, at least there were several main factors faced by farmers, namely the condition of damaged housing, damaged and non-producing business land and affecting household income and non-functioning business institutions, although in the long term the agricultural land affected by the eruption would be far away become more fertile, but it takes a relatively long time. Therefore, efforts are needed to address these factors so that farmers suffer less. To be able to make efforts to reduce these risks, data and information are needed on the impact of the Sinabung eruption on the socio-economic conditions of the population.

Hafni and Lubis (2016) research on The impact of the eruption of Gunung Sinabung on the socio-economic conditions of farmers in Suka Meriah Village, Umbrella District, Karo Regency. In the research conducted, the authors highlight the problems and impacts of the post-eruption disaster of Gunung Sinabung in relation to the socio-economic conditions of families in Suka Meriah Village in Suka Meriah Village, Payung District, Karo Regency who work as farmers, namely by comparing the socio-economic conditions of the community before and after the eruption of Gunung Sinabung in Tanah Karo.

Suharyanto (2019), regarding the survival strategy of the people living in the relocation of Siosar, shows that the people of Suka Meriah Village still have problems after being relocated to Siosar such as weather conditions, crop production, transportation, and lack of water. Meanwhile, the strategies carried out by the community are active strategies, passive strategies and network strategies. In addition, there is also the level of community welfare which can be seen from the sufficiency of primary integrity, environmental security, education and health.

Suharyanto, et al (2018), Research on efforts to maintain work customs in the Karo community in the Siosar relocation area. The results of the study indicate that there is no change in the meaning of annual work carried out and there have been slight changes that are not striking, because there are new rules stipulated in the implementation of annual work for Karo people after relocation to Siosar.

Kaban, et al (2021), Kegeluhen Mbaru Ibas Kuta Siosar (Socio-Cultural Changes in the Community in the Disaster Relocation Area), the results of the study stated that the difference between working years in their place of origin and in Siosar, was not very visible and conspicuous, because there was a new agreement in the new area. In addition, there are still 
some traditions that are still carried out in Siosar Relocation in the custom of the Karo people, namely the ritual of rejecting bala sarilala.

Purba (2016), Household Survival Strategy for Victims of the Sinabung Eruption Post Relocation in Siosar, Brand District, Karo Regency. Communities living in the Relocation area in Sisosar, must continue to provide for themselves and all family members. Therefore, the community must carry out a strategy to be able to sustain life and seek sustainable livelihoods independently, without having to depend on programs and policies from the government.

The objectives to be achieved in this study are first, to determine the distribution of shelter and agriculture and the impact on the community in the Siosar Refugee Relocation.

\section{Research Method}

The method used in this study uses descriptive qualitative research method, according to Bogdan and Tylor in (Moleong, 2005) which aims to present a picture of the social reality that exists in society by describing phenomena in the areaQualitative methods produce descriptive data in the form of written or spoken words from observable people or actors. In addition to field research, literature studies are also conducted to add to the literature relevant to the research conducted.

\section{Result and Discussion}

\subsection{Distribution of Shelters and Agriculture to Communities in the Siosar Refugee Relocation}

Not only settlements were badly damaged, but also the land where people farmed was destroyed and lost. Another reason residents agree to this resettlement activity is the existence of Suka Meria village, which is located within a radius of $3 \mathrm{~km}$ and is a potential location for the spread of hot clouds. It is quite dangerous to live in a village because it can be fatal if there is still human activity in the village. People must be afraid to return to their hometowns to see the ongoing eruption of Gunung Sinabung.

Before the Sinabung eruption, Suka Meriah village was a village known for its fertile arable land for agricultural commodities, especially vegetables, not only that, Suka Meriah Village was also known for its very cool air because the surroundings of the village were surrounded by forest, public bathrooms with shower water. also flows for a full day without stopping because the village is very close to the spring. But now the village is covered in very thick volcanic ash until now the village is even like a barren desert filled with hundreds of tons of volcanic ash material from the vomit of Gunung Sinabung. Not a single residential building was seen in Suka Meriah Village.

The people of Suka Meriah Village strongly agree if they are relocated from their home area to the Siosar area as a relocation destination. The reasons that underlie them agree with the relocation activities include the original location can no longer be lived in, the source of livelihood has been lost and the community is afraid of the threat of danger in the future. The first reason the community agrees with the settlement relocation plan is that the original location as a residence for the people of Suka Meriah Village has been destroyed so that it is no longer suitable for habitation to be occupied. 
In general, the people of Suka Meriah Village are very eager for the relocation to be realized immediately and they can be immediately moved to the Siosar area. At this time, the people who will be relocated, especially the people of Suka Meriah Village, are no longer in refugee locations scattered at several points in Karo Regency, but have determined their own place of residence independently. The government has provided assistance funds to the refugees so that they can continue to live and fulfill their daily needs even though they are no longer in refugee camps.

The people of Suka Meriah Village in general do not have special requests for the construction of the new settlements, they accept whatever type and form of housing will be provided to them. There are no significant settlement criteria demanded by the people of Suka Meriah Village, which means that all forms and types of settlements offered by the government are well received by the people of Suka Meriah Village. But the emphasis is always on the demand for agricultural land, when they feel it is useless if they are only given a house without agricultural land, because most of them grow and live from agriculture. As said by Mr. Karo-karo, one of the people of Suka Meriah Village "We don't want to move if we don't get a field".

\subsection{The Impact of the Suka Meriah Village Community on the Division of Housing and Agriculture in Siosar}

The impact of the Suka Meriah Village community regarding the division of housing and agriculture in Siosar is where The type of house built in the new settlement is a simple type house. This house has its own advantages and disadvantages. When viewed in terms of shortcomings, this house has a space that is not too wide and very limited. This house consists of one bedroom, one bathroom, and also only has one main room which is used for various activities. On average in one family there are 4-5 people, with such a house condition, of course, greatly limits the movement space of the family. The majority of the people of Suka Meriah Village are farmers. Their types of crops include corn, coffee, cloves, potatoes, chilies, onions and tomatoes.

The name of one of our informants is Mrs. Alfarizi Br Sembiring who lives in the village of Suka Meriah. Who has lived in the village for a long time. After we asked about their village, they had been relocated several times to other places, such as near the GBKP church, with an air route, some to the Tanah Karo district head office and the Tanah Karo sub-district office located in Kabanjahe. Then we also asked questions about the division of housing and agricultural land. According to Mrs. Alfarizi, it is true that for the distribution of housing in each village, each family gets an area of about $10 \times 20$ meters of house land and for agricultural land, each family gets half a hectare of land.

With the stipulation that if the residents who lived in the previous village had the original family card from the village, they would get one housing unit with an area of 10x20 meters and half a hectare of agricultural land. However, if the resident does not have an original family card in the village prior to relocation or for immigrants but has lived in the previous village for a long time, the resident only gets half a hectare of agricultural land. And for the place to live, it is provided but it must be contracted, said the mother. Indeed, this provision has been set by the government and is officially inviolable.

According to Mrs. Sirait, the villagers like to be lively, also think that after being relocated to their current place they can add or make small stalls to sell, because the mother used to sell in the previous village, so even in the village, she still sells. Like selling rice and 
snacks for children. The number of houses built in this village corresponds to the number of households, which are 128 units in this new possible location. And for the type of house that was built in the new settlement, it is a type 36 house, this house has advantages and disadvantages, when viewed from the point of view of the shortcomings, this house has a room that is not too wide and very limited.

We also asked the husband of Mrs. Alfarizi Br Sembiring, namely Mr. Karo-karo, here we asked how the majority in the village like Meriah. And according to Mr. Karo-karo, the majority of Suka Meriah Villagers are generally farmers of the types of crops they plant on agricultural land that has been provided by the government such as Corn, Coffee, Chili, Onions and Tomatoes, and currently they are taking care of growth chili because it will soon bear fruit. After we asked the father in this village, the community still uses the "Aron" system. Aron means a concept of a pattern of cooperation and mutual help in the Karo tribe.

According to Mr. Karo-karo, the community here still maintains the aron and is still doing it where, the members of this aron will work in neighboring villages to help the neighboring community but earn wages according to the provisions of the community. The father had also followed this aron to his neighboring village, namely to Simacem Village. On the other hand, Simacem people can also follow aron to Suka Meriah Village. There are also people who do not have time to manage their land, so he invites Aron to work on his land and pays according to a mutual agreement.

According to Pak Karo-Karo, the problem of income has changed greatly by living in the previous village compared to the current one. but still fulfilled despite having a very big change because the father said he used to have a large area of land and citrus plants. And getting more income than what we are now only given half a hectare of land, said the father. And getting a small income, it so happens that your mother has additional income from selling in this shop, the income is still fulfilled, said the father.

\section{Conclussion}

The people of Suka Meriah Village in general are people who depend on agricultural land for their lives. The house for their residence, there are no specific criteria and will accept any type and form of housing that will be provided by the government. They place more emphasis on demand for agricultural land, when they feel it is useless if they are only given a house without agricultural land, because most of them grow and live from agriculture.

The problem of income, has become very influential on the people of Suka Meriah village, income has changed greatly by living in the previous village compared to the current one. However, even though it is reduced, it is still fulfilled even though it has a very large change. 


\section{References}

Fhadila dan Lestari (Eds). (2013). Pengertian Persepsi, Bandung: Media Press

Fhadila dan Lestari (Eds). (2013). Peran Fungsi Pembelian, Jakarta: 13220

Gunawan et al. (2014), Metode Penelitian dan tekhnik pengumpulan data, jakarta: Direktorat Tenaga Kependidikan

Hafni, R., \& Lubis, L. S. (2016). Dampak erupsi gunung sinabung terhadap kondisi Sosial ekonom petani di desa suka meriah Kecamatan payung kabupaten karo. Jurnal Ekonomikawan, 16(1), 77828.

Idrus, M., (Eds). (2009). Model Interaktif, Jakarta, Indonesia: Erlangga

Kaban, J. D. B., Darmawan, D. R., \& Siburian, S. J. (2021). Kegeluhen Mbaru Ibas Kuta Siosar (Perubahan Sosial Budaya Masyarakat Di Kawasan Relokasi Bencana). Culture \& Society: Journal Of Anthropological Research, 2(4), 172-178.

Lusi, R., dan Priyo, D., (2014), Dampak Erupsi Gunung Merapi Terhadap Lahan dan UpayaUpaya Pemulihannya. Surakarta.Vol XXIX No. 1

Muary, R., Suharyanto, A., Sihite, O., \& Nasution, J. (2020). Hutabolon Village Community Behavior in Overcoming Health Problems. Lakhomi Journal Scientific Journal of Culture, 1(1), 36-43.

Nugraha, D.S. \& Sulastri, L (2018). Pengaruh Faktor Kompetensi Perencana, Faktor Data, Serta Faktor Anggaran terhadap Efektivitas Perencanaan Penanggulangan Bencana Alam di Kabupaten Sumedang. Jurnal Administrasi Publik : Public Administration Journal : Public Admnistration Journal (Public Administration Journal). 8 (2): 172-177

Purba, I. (2016). Strategi Bertahan Hidup Rumah Tangga Korban Erupsi Sinabung Pasca Relokasi Di Siosar Kecamatan Merek Kabupaten Karo (Doctoral dissertation, UNIMED).

Ramadhan, I, dan Armansyah M., (2016). Peran Badan Penanggulangan Bencana Daerah Daerah Kota Medan dalam Penanggulangan Bencana Alam, JPPUMA: Jurnal Ilmu Pemerintahan dan Sosial Politik UMA (Journal of Governance and Political UMA), 4 (2): 173-181

Rambe, A., \& Amir, P., Usman, T., (2016), Analisis Pemberdayaan Pegawai Badan Penanggulangan Bencana Daerah (Bpbd) Kota Medan, Jurnal Administrasi Publik, 6 (1): 20-30.

Simamora, R. et al. (2021). The Influence of Awareness of Taruna Coral Youth on the Mitigation of Longsor Land Disaster in the North Tapanuli Regency. Budapest International Research and Critics Institute-Journal (BIRCI-Journal). P. 4110-4115

Suharyanto, A. (2019, August). Strategi Bertahan Hidup (Live Survival Strategy) Masyarakat Desa Suka Meriah Pasca Relokasi di Siosar. In Proceeding ICOPOID 2019 The 2nd International Conference on Politic of Islamic Development (Vol. 1, No. 1, pp. 211 227).

Suharyanto, A., Ginting, D. Y., Rajagukguk, K. M. B., Pebrianti, N., Panggabean, R. M., \& Tanjung, S. Makna Pesta Kerja Tahun pada Masyarakat Karo Siosar Pasca Bencana Alam Gunung Sinabung. Gondang: Jurnal Seni dan Budaya, 2(1), 36-44.

Tylor dan Bogdan. (2005), Pendekatan Metode Penelitian dan Jenis Penelitian, Jakarta: Direktorat Tenaga Kependidikan 